\title{
Hunting success of the weasel Mustela nivalis and escape tactics of forest rodents in Białowieża National Park
}

\author{
Włodzimierz JĘDRZEJEWSKI, Bogumiła JĘDRZEJEWSKA ${ }^{1}$ \\ and Ewen McNEISH
}

\begin{abstract}
Jędrzejewski W., Jędrzejewska B. and McNeish E. 1992. Hunting success of the weasel Mustela nivalis and escape tactics of forest rodents in Białowieża National Park. Acta theriol. 37: 319 - 328 .

Visual observations of five radiotracked male weasels Mustela nivalis Linnaeus, 1766 hunting rodents are reported. The weasels hunted bank voles Clethrionomys glareolus and yellow-necked mice Apodemus flavicollis in the primeval deciduous forests of the Białowieża National Park, Eastern Poland. Densities of rodents were high as a consequence of mast crop in the year preceding the observations. A total of 60 attacks by weasels were observed from October till December 1990 . Weasels encountered voles and mice at a 1:1 ratio, similar to the ratio these rodents were captured in live traps (1:0.8). Only $23 \%$ of weasel attacks on voles, against $60 \%$ of those on mice, were successful. Out of 30 attacks on bank voles, 22 were on solitary voles and 8 on social groups of $2-4$ voles. Bank voles were found by weasels in underground dens and on the ground. Out of 30 attacks on mice, 19 were on solitary individuals and 11 on groups of $2-6$ mice. Mice were encountered by weasels in underground dens and in cavities located $1-4 \mathrm{~m}$ up old trees. It is suggested that the mechanism of greater susceptibility of mice to weasel predation in autumn and early winter lies in the physiology of mice, i.e. in their daily torpor. When hunting bank voles, the weasels were more successful with solitary voles than with social groups. By contrast, attacks on groups of mice were more successful than those on solitary mice. In both species, the rodents in groups benefited from the 'dilution effect' in a group and had a higher probability of surviving weasel attacks than did solitary rodents. The antipredatory defence most frequently observed in both species of rodents was running out of a burrow or cavity when a weasel entered it. Mice often escaped by running away and climbing trees.
\end{abstract}

Mammal Research Institute, Polish Academy of Sciences, 17-230 Białowieża, Poland (WJ, BJ); Farnborough College of Technology, Farnborough, Hampshire, Great Britain (EM)

Key words: Mustela nivalis, hunting success, rodent escape behaviour, Białowieża National Park, Poland

\section{Introduction}

Weasel-rodent relationships are those of a highly specialized predator and its prey (Erlinge 1975, King 1980). Due to its small size and elongated body, the weasel Mustela nivalis Linnaeus, 1766 is capable of pursuing rodents not only

${ }^{1}$ Present address of BJ: Workshop for Ecology and Protection of the Natural Environment, P. O. Box 23, 17-230 Białowieża, Poland 
on the ground but also in underground tunnels and subnivean spaces. The mutual relationship between the bank vole Clethrionomys glareolus and weasel, as revealed by behavioural experiments, is based on the vole's recognition of weasel scent and adaptations to avoid the risk of weasel predation. This includes abandoning places tainted with weasel scent, taking arboreal and on-ground escape, and changing their daily activity rhythms (Jędrzejewska and Jędrzejewski 1990, Jędrzejewski and Jędrzejewska 1990). Reproduction of bank voles may be suppressed by the presence of a weasel (Ylonen 1989). No experiments have been conducted on Apodemus' response to the risk of weasel predation.

Field data on weasel-rodent relationships are rare. King (1980) estimated that in Wytham Wood, England, weasels killed $8 \%$ of the standing crop of bank voles per month (range $2-20 \%$ ) and $10 \%$ of wood mice Apodemus sylvaticus (range 1 - 20\%). In Białowieża National Park, during 200 days of autumn and winter weasels removed about $15 \%$ of the autumn numbers of bank voles and $9 \%$ of yellow-necked mice Apodemus flavicollis (Jędrzejewski and Jędrzejewska 1993).

There is an obvious gap in our knowledge between the experimentally obtained data on the behaviour of individual prey and predator, and the results of field studies on the population ecology of weasels and rodents. Some of the unanswered questions include: how do weasels overcome the antipredatory defences of rodents, and what is the weasel's hunting success towards prey species with various escape tactics?

In this paper we report on observations of radiotracked male weasels hunting bank voles Clethrionomys glareolus (Schreber, 1780) and yellow-necked mice Apodemus flavicollis (Melchior, 1834) in autumn during very high densities of these rodents. The studies were undertaken in the pristine broadleaf forests, typical of the lowlands of Central and Eastern Europe. Prey choice by weasels, their hunting success, and hunting modes as well as escape tactics by rodents were described and quantified. The study was part of a long-term research project on predator-prey relationships in the Białowieża National Park (e.g. Jędrzejewski et al. 1989).

\section{Study area}

Białowieża National Park $\left(47.5 \mathrm{~km}^{2}, 52^{\circ} 43 \mathrm{~N}, 23^{\circ} 54^{\prime} \mathrm{E}\right)$ protects the last remnants of virgin lowland deciduous forests in Europe, unaltered by timber exploitation and other human activity. The mature woods are dominated by oak Quercus robur, hornbeam Carpinus betulus, linden Tilia cordata, maple Acer platanoides, and spruce Picea abies. The average age of tree stands is 130 years, and their structure is typical of multi-layer, multi-species forests, with the regeneration of trees taking place under the canopy of the old stand. Numerous windfallen and uprooted trees make the habitat diverse.

Rodent trapping as well as livetrapping and radiotracking of weasels took place in the southcentral part of the Park, in the oak-linden-hornbeam forest association. A detailed description of the vegetation of forest associations is given in Faliński (1986).

At the time of trapping, weasels were the most numerous mammalian predator in the Park. During the winters of $1985 / 86$ to $1988 / 89$ their densities varied from 17 to 27 individuals per $10 \mathrm{~km}^{2}$ (Jędrzejewski and Jędrzejewska 1993). In 1990, when rodent densities were very high after the mast crop of oak and hornbeam (in 1989), weasel densities increased markedly. 


\section{Methods and material}

Rodents were livetrapped using the Catch-Mark-Release method on the 3.24-ha area in May, July, September, and November 1990, and in April, May, July, September, and November 1991. Each trapping series lasted 6 days. Traps (Polish wooden box, see Olszewski 1968) were distributed in a $15-\mathrm{m}$ grid and baited with parched oats.

The livetrapping of weasels was undertaken at 2-month intervals in 1990 and 1991. Standard wooden flip-door box traps, with a separate bait compartment were used, and set every $50 \mathrm{~m}$ along the forest path at ground level under fallen logs or adjacent to root plates. A total of 38 traps were used. Two live white mice were used as bait and given food and bedding. Traps were checked twice daily at 9.00 a.m. and 7.00 p.m. in summer, and at 9.00 a.m. and 4.00 p.m. in late autumn.

On capturing a weasel, it was immediately given fresh bait and then taken to the laboratory and anaesthetised. During this time its sex was determined, weight recorded, and its ear marked by incision. A radio collar (3.5 to 4.9 grams, AVM Instrument Company, Ltd., Livermore, CA) was fitted around the weasel's neck. After radio-collaring it was released into an outdoor enclosure (at the Mammal Research Institute, Białowieża), approximately $4.5 \times 12 \mathrm{~m}$, which was equipped with vegetation, logs, live rodents and a nest box with meat and water. Within the next $1-2$ days the weasel was observed at various times in the enclosure to see how it adapted to the extra weight. When the first killed rodents were found in the weasel's nest box, it was then caught from the enclosure and released back to the forest in exactly the same place where it was originally caught.

The weasel's movements were followed with a portable radio telemetry set. The range of the transmitted signal varied from 100 to $400 \mathrm{~m}$, usually about $200 \mathrm{~m}$. The movements of the weasel were plotted on a base map. It was often possible to observe the weasel from a distance of 5-15 m without disturbing its activity. All radiotracked weasels were diurnal with two peaks of daily activity, in the morning and early afternoon (W. Jędrzejewski et al., in prep.). All observations of weasels hunting rodents were collected between 7.15 a.m. and 3.15 p.m. Only those observations, in which the species of prey was seen and identified are described in this paper. External differences of two main species of forest rodents, the bank vole and the yellow-necked mouse, allowed for the visual determination of prey species.

When a weasel entered a burrow or tree cavity inhabited by rodents, the rodents immediately escaped. A weasel attack was considered successful, if a weasel emerged from a den or cavity with prey in its mouth, or (in 3 cases) when 1 or 2 rodents escaped from a nest and a weasel remained in it for over 1 hour. The attack was considered unsuccessful, if a weasel pursued escaping rodents but neither captured one nor remained in one place for some time. In all observed attacks, the rodents seen escaping from one place plus those killed there by a weasel, were considered to have shared one nest. The group size of rodents assessed this way may be somewhat underestimated because at least in some cases few rodents did not show up.

Of 69 observed attacks, 60 (by 5 weasels) occurred from the 10th of October to 21st of December 1990, and 9 attacks (by 3 weasels) occurred during February, May and August 1991 (Fig. 1). In autumn 1990, weasels killed exclusively rodents. In 1991, 8 rodents and 1 mole Talpa europaea were captured by weasels. Nine observations from 1991 were analysed separately because they represented very different environmental conditions and extremely low rodent numbers. Observations of the mode of weasel hunting, prey behaviour and place of attack were also noted.

\section{Results}

\section{Numbers of forest rodents}

After the mast year of oak and hornbeam in 1989, both yellow-necked mice and bank voles bred in winter 1989/90 (Z. Pucek et al., in prep.) and their numbers 
continued to increase till July - September 1990 (Fig. 1). In September, 391 mice and 480 voles were present on the 3.24-ha trapping area (Minimum Number Alive). After September, both species declined rapidly till May 1991, when only 3 mice and 3 voles were found. The extremely low numbers were recorded throughout the whole of 1991 (Fig. 1).

In 1990 , reproduction ceased in autumn. In September, $13 \%$ of female mice and $7 \%$ of female voles were pregnant. In November, no female mice and only $1 \%$ of female voles were pregnant.

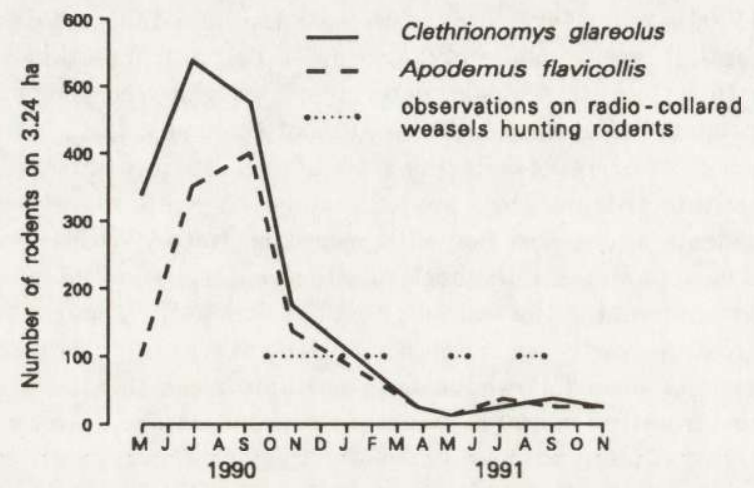

Fig. 1. Dynamics of ' rodent numbers in the pristine oak-linden-hornbeam forests of Białowieża National Park; outbreak in 1990 followed the mast crop in 1989. Numbers of rodents - number of individuals livetrapped and marked in the 3.24-ha study plot.

\section{Selection of prey species and differentiated hunting success in weasels}

Out of 30 'groups' of bank voles that weasels attacked in autumn and winter 1990, 22 v'ere solitary individuals. The largest group included 4 voles (Table 1). A total of $26 \%$ of bank voles were in groups of $2-4$ individuals. Yellow-necked mice were slightly more 'social' (Table 1). The largest group (out of 30 'groups' located by weasels) contained 6 mice, and a total of $36 \%$ of mice were in groups of $2-6$ individuals. All rodents ( 5 mice and 3 voles) pursued by weasels in spring and summer 1991 were solitary.

Table 1. Social groups of bank voles Clethrionomys glareolus and yellow-necked mice Apodemus flavicollis as determined by observations of hunting weasels from October till December 1990 in the Białowieża National Park.

\begin{tabular}{lcrrrrrrrr}
\hline \multirow{2}{*}{ Species } & & \multicolumn{9}{c}{ Groups of: } & \multicolumn{3}{c}{$\begin{array}{c}\text { Mean group } \\
\text { size }\end{array}$} \\
& & 1 & 2 & 3 & 4 & 5 & 6 & (SD) \\
\hline Bank vole & ngroups & 22 & 6 & 1 & 1 & - & - & 1.37 & $(0.72)$ \\
& $\%$ & 74 & 20 & 3 & 3 & - & - & & \\
Yellow-necked mouse & ngroups & 19 & 5 & 3 & 1 & 1 & 1 & 1.77 & $(1.30)$ \\
& $\%$ & 63 & 17 & 10 & 3 & 3 & 3 & & \\
\hline
\end{tabular}


In autumn and winter, weasels encountered voles and mice roughly at the same ratio $(1: 1)$ at which these two species were captured in live traps in September and November (1:0.8). Totally, $42 \%$ of observed attacks on rodents were successful. The weasels killed $26(28 \%)$ rodents out of 94 subject to attack in autumn and early winter (Table 2). However, the species differed significantly (Table 2): only $23 \%$ of attacks on voles, against $60 \%$ of those on mice, were successful $(1: 2.6)(\mathrm{G}=8.4$, d.f. $=1, p<0.005, G$-test $)$.

When hunting bank voles, the weasels were more successful with solitary voles. By contrast, attacks on social groups of yellow-necked mice were more successful than those on solitary mice (Table $2 ; \mathrm{G}=51.2$, d.f. $=1, p<0.001$ ). However, in both species of prey, after the weasel had located the nest, rodents in huddles had a higher probability of surviving the weasel attacks than did solitary rodents. Although the bank voles' overall chances of surviving were higher than those of mice, in both species the gain in survival when huddled was similar ( $22 \%$ in bank voles and $18 \%$ in mice in comparison to solitary rodents' chances of survival) (Table 2).

The higher success when hunting mice was the same for each of the three weasels of which the largest number of observations was gathered. Weasels numbered 10, 8 and 4 encountered bank voles as frequently as yellow-necked mice (4 and 6 attacks on mice and voles respectively by weasel No. 10;14 and 17 attacks by No. 8 ; and 8 and 6 attacks by No. 4). Success of attacks on mice was higher than those on bank voles by the three weasels: 5 mice killed out of 12 subject to

Table 2. Hunting success of weasels attacking bank voles and yellow-necked mice. Data for 5 radiotracked weasels pooled.

\begin{tabular}{lccc}
\hline Parameter & All rodents & Solitary rodents & Rodents in groups \\
\hline & Clethrionomys glareolus & \\
n attacks & 30 & 22 & 8 \\
\% successful attacks (n) & $23 \%(7)$ & $27 \%(6)$ & $12 \%(1)$ \\
n rodents subject to attack & 41 & 22 & 19 \\
\% rodents killed (n) & $17 \%(7)$ & $27 \%(6)$ & $5 \%(1)$ \\
& & & \\
n attacks & Apodemus flavicollis & & \\
\% successful attacks (n) & 30 & 19 & 11 \\
n rodents subject to attack & $60 \%(18)$ & $47 \%(9)$ & $32 \%(9)$ \\
\% rodents killed (n) & 53 & 19 & 34 \\
& $36 \%(19)$ & $47 \%(9)$ & $29 \%(10)$ \\
n attacks & \multicolumn{4}{c}{ Total } & & 19 \\
\% successful attacks (n) & $42 \%(25)$ & $37 \%(15)$ & $53 \%(10)$ \\
n rodents subject to attaek & 94 & 41 & 53 \\
\% rodents killed (n) & $28 \%(26)$ & $37 \%(15)$ & $21 \%(11)$ \\
\hline
\end{tabular}


attack $(5 / 12)$ by weasel No. $10,6 / 24$ by weasel No. 8 , and $3 / 8$ by No. 4 . Hunting for bank voles was always less successful: 3 voles killed out of 6 subject to attack (3/6) by weasel No. $10,1 / 19$ by weasel No. 8 , and $2 / 11$ by No. 4 .

\section{Weasels' hunting modes and rodents' escape tactics}

Weasels hunted using a systematic search of underground dens and tunnels of rodents, and cavities located $1-4 \mathrm{~m}$ up old trees. On 51 attacks, the place of encounter was reliably determined, $22 \%$ were in tree cavities and $33 \%$ in underground hides of rodents (Table 3). In fact, the proportion of rodents encountered by weasels in their underground dens was still higher, because most of the rodents captured on the ground were those that had been chased by a weasel out of their dens. Only yellow-necked mice were found in tree cavities. All bank voles were found in underground dens or on the ground, foraging amongst the vegetation.

In most successful hunts, a weasel entered a rodent nest or cavity, and after a short while it emerged with a captured rodent in its mouth. On 12 occasions, however, a particular hunting technique was observed. These included: digging in the ground to enlarge the hole entrance ( 3 observations), obvious using its sense of smell ( 2 observations, both on bank voles as prey), locating the rodent by listening ( 1 obs.), and chasing a rodent ( 6 observations, all involving yellow-necked mice). The chase was usually $5-20 \mathrm{~m}$ long, but may have lasted for as long as 2 minutes. It included climbing trees by both prey and predator, and jumping off the bushes $(3 \mathrm{~m})$ onto the ground. On one occassion, a female mouse with new-born offsprings attached to her nipples was chased by a weasel. She climbed a linden tree and managed to escape, but some of the young fell off as she entered a crevice in the bark $0.5 \mathrm{~m}$ up the trunk. The weasel neither captured the female nor found the lost young.

When found and approached by a weasel in their den or cavity, the rodents most often attempted to run out of it. Bank voles ran on the ground and were not

Table 3. Places of weasel attacks on forest rodents. Localities of bank voles and yellownecked mice differed significantly $(\mathrm{G}=18.0$, d.f. $=2, p<0.001, G$-test).

\begin{tabular}{lcccc}
\hline Prey & & $\begin{array}{c}\text { Cavities } \\
\text { in trees }\end{array}$ & $\begin{array}{c}\text { Underground dens } \\
\text { and tunnels }\end{array}$ & $\begin{array}{c}\text { On the } \\
\text { ground }\end{array}$ \\
\hline Clethrionomys glareolus & $\mathrm{n}$ & - & 12 & 12 \\
& $\%$ & - & 50 & 50 \\
Apodemus flavicollis & $\mathrm{n}$ & 11 & 5 & 11 \\
& $\%$ & 41 & 18 & 41 \\
Total & $\mathrm{n}$ & 11 & 17 & 23 \\
& $\%$ & 22 & 33 & 45 \\
\hline
\end{tabular}


observed climbing trees. When approached by a weasel on the ground, bank voles disappeared amongst the vegetation or dead leaves and sometimes were observed to stay immobile ( 2 observations). On one occasion, a bank vole was seen climbing a stinging nettle stem. Yellow-necked mice did not stay calm and immobile, and they often climbed trees or shrubs after having run out of their den or cavity (12 observations, $32 \%$ of observed escaping mice).

\section{Discussion}

Before we proceed to interpret and discuss the presented data, we should emphasize their restrictions. Firstly, the observations are representative of high numbers of rodents. In deciduous lowland forests of Central Europe, such outbreaks occur at 6-9-year intervals in consequence of mast crop (Z. Pucek et $a l$., in prep.). Secondly, the data represent autumn and early winter, when the reproductive season of rodents is usually over. Thirdly, only male weasels, which are larger than females, were radiotracked.

The hunting success of radiotracked weasels attacking forest rodents was $42 \%$. In the outdoor enclosure of $50 \mathrm{~m}^{2}$ in seminatural conditions, but with extremely high densities of bank voles (equivalent to about 2,000 voles $\times \mathrm{ha}^{-1}$ ), weasels captured voles on 4 occasions out of 13 attacks (31\%) (W. Jędrzejewski, unpubl. observations, October 1986). Therefore, a weasel, seemingly "an effective mouse-trapping machine" (King 1989), does not in fact differ much from other predators, the hunting efforts of which include more failures than successes. No comparative data are available about other small-sized predatory mammals. However, the hunting success of large predators is usually low, e.g. $5 \%$ in wolves (Mech 1970), 26\% in lions (Schaller 1972), 32\% in hyeanas (Kruuk 1972).

The radiotracked weasels weighed from 75 to $123 \mathrm{~g}$ (92 g on average). In autumn 1990 , bank voles weighed from 8 to $28 \mathrm{~g}$ ( $15 \mathrm{~g}$ on average) and yellow-necked mice

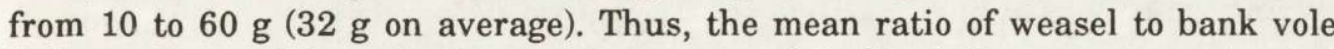
body mass was $6: 1$, and of weasel to mouse - 3:1. The latter one approximates, for instance, the relationship between wolf and roe deer Capreolus capreolus.

Obviously, the high success of rodents in surviving weasel attacks was due to the well developed and differentiated antipredatory behaviour of rodents. Antipredatory defences of bank voles were studied in detail in enclosure or laboratory experiments (Jędrzejewska and Jędrzejewski 1990, Jędrzejewski and Jędrzejewska 1990). In our observations in the Białowieża National Park, the most frequent escape tactic of both species of rodents was running out of the den or burrow. Rodent burrows have many entrances and a rather complicated pattern (Montgomery and Gurnell 1985). Also the cavities in hollow trees occupied by yellow-necked mice have more than one 'emergency exit'. The weasel often entered the hole in the trunk at the base of the tree, climbed inside the trunk, whereas the mice were seen jumping off the cavity located some $1-4 \mathrm{~m}$ up the tree. 
In laboratory experiments (W. Jędrzejewski et al., in prep.) bank voles were exposed to the scent of 6 species of predatory mammals and were offered rubber tubes as substitutes to tunnels. The voles reluctantly hid in them and preferred to stay out of the tubes in response to the odours of a weasel, stoat Mustela erminea, and stone marten Martes foina. The odours of red fox Vulpes vulpes, raccoon dog Nyctereutes procyonoides, and polecat Mustela putorius did not change the voles' utilisation of tubes.

Other antipredatory behaviours observed in the Białowieża National Park included immobility and climbing herbaceous plants by bank voles (also observed in laboratory experiments, W. Jędrzejewski et al., in prep.), and climbing trees and fleeing by yellow-necked mice. The differentiated escape tactics by voles and mice are determined by morphology and locomotory abilities of these species.

In both species of rodents, huddling appeared to have an antipredatory advantage. Huddling in bank voles and yellow-necked mice was reported to improve thermoregulation in rodents, which may be important in late autumn and winter (Gębczyński 1969, Fedyk 1971).

The antipredatory advantage of grouping in small rodents does not rely on a decreased scanning rate per individual as in most birds and mammals (review in Elgar 1989), but on the decreased probability of capturing any one individual by a predator. In our observations, only once did a weasel kill two mice from one huddle; it returned to seek the escaped rodents after having killed and stored the first one. Therefore, the weasels' attack rate was independent of the group size (in all cases except one, a weasel killed a single prey from an attacked group), and an individual rodent benefited from the dilution effect within a group (see Pulliam and Caraco 1984).

It must be remembered, however, that the real distribution of rodents within the study area was not known. It is likely, that relatively more animals were single and were not found by weasels. If so, single individuals would be most successful in avoiding predation.

Why were yellow-necked mice more susceptible to weasel predation than bank voles? It seems to contradict the opinion that Apodemus mice (as granivores with shorter alimentary tracts and better escape abilities) are less vulnerable to predation than microtines (as herbivores with long alimentary tracts and clumsy bodies) (Hansson 1987). We think that the mechanism of greater susceptibility of mice to weasel predation lies in the physiology of mice. At low ambient temperatures, Apodemus flavicollis, the normal body temperature of which is $37^{\circ} \mathrm{C}$, may show non-lethal hypothermia and for some periods it may decrease its body temperature even to $12^{\circ} \mathrm{C}$ (Cygan 1985). Like the closely related Apodemus sylvaticus (compare Morris 1968, Walton and Andrews 1981), the yellow-necked mouse can enter short spells of torpor as a strategy of saving energy in autumn and winter. Microtines do not have such adaptations (Wunder 1984). Walton and Andrews (1981) reported that in small mammals of a nocturnal type of activity, short daily torpor comes often during late morning hours. 
During our study, the mean daily temperature was $8.1^{\circ} \mathrm{C}\left(\min 1.9^{\circ} \mathrm{C}\right)$ in October, $3.8^{\circ} \mathrm{C}\left(\min 0.5^{\circ} \mathrm{C}\right)$ in November, and $-0.8^{\circ} \mathrm{C}\left(\min -6.3^{\circ} \mathrm{C}\right)$ in December 1990. Snow was present in December (mean daily cover $17 \mathrm{~mm}$, $\max 40 \mathrm{~mm}$ ). At such low ambient temperatures mice were certainly entering their daily torpor.

Also Northcott (1971) reported that in the Canadian Arctic, the hibernating Zapus hudsonicus were the most common prey for the stoat Mustela erminea although other species of rodents were more abundant. Therefore, besides morphology, the physiological adaptations of rodents to energy saving may crucially affect their antipredatory abilities in autumn and winter.

Acknowledgements: We are grateful to K. Zub, W. Nowakowski, E. Bujko and Earthwatch Research Corps for their help in radiotracking weasels, and to L. Szymura for computer data input. E. McNeish was sponsored by the Vincent Wildlife Trust for his one-year research training at the Mammal Research Institute, Polish Academy of Sciences, Białowieża. We thank Mrs. B. Kermeen, the director of the AVM Instrument Co. Ltd. for her unfailing support. The project was financed by the Earthwatch grant and by the Mammal Research Institute budget. We thank Drs J. Gliwicz, T. Oksanen and Z. Pucek for their comments.

\section{References}

Cygan T. 1985. Seasonal changes in thermoregulation and maximum metabolism in the yellow-necked field mouse. Acta theriol. 30: $115-130$.

Elgar M. A. 1989. Predator vigilance and group size in mammals and birds: a critical review of the empirical evidence. Biol. Rev. 64: 13 - 33.

Erlinge S. 1975. Feeding habits of the weasel Mustela nivalis in relation to prey abundance. Oikos 26: $378-384$.

Faliński J. B. 1986. Vegetation dynamics in temperate lowland primeval forests. Dr. W. Junk Publishers, Dordrecht. Geobotany 8: $1-537$.

Fedyk A. 1971. Social thermoregulation in Apodemus flavicollis (Melchior, 1834). Acta theriol. 16: $221-229$.

Gębczyński M. 1969. Social regulation of body temperature in the bank vole. Acta theriol. 14: $427-440$.

Hansson L. 1987. An interpretation of rodent dynamics as due to trophic interactions. Oikos 50: $308-318$.

Jędrzejewska B. and Jędrzejewski W. 1990. Antipredatory behaviour of bank voles and prey choice of weasels - enclosure experiments. Ann. Zool. Fennici 27: 321 - 328.

Jędrzejewski W. and Jędrzejewska B. 1990. Effect of a predator's visit on the spatial distribution of bank voles: experiments with weasels. Can. J. Zool. 68: 660-666.

Jędrzejewski W. and Jędrzejewska B. 1993. Predation on rodents in Białowieża Primeval Forest, Poland. Ecography 16 (in press).

Jędrzejewski W., Jędrzejewska B. and Szymura A. 1989. Food niche overlaps in a winter community of predators in the Białowieża Primeval Forest, Poland. Acta theriol. 34: 487 - 496.

King C. M. 1980. The weasel Mustela nivalis and its prey in an English woodland. J. Anim. Ecol. 49: $127-160$.

King C. 1989. The natural history of weasels and stoats. Christopher Helm Publ. Ltd., Bromley, UK. $1-253$

Kruuk H. 1972. The spotted hyaena. Univ. Chicago Press, Chicago and London.

Mech L. D. 1970. The wolf: the ecology and behaviour of an endangered species. Natural History Press, New York. 
Montgomery W. I. and Gurnell J. 1985. The behaviour of Apodemus. [In: The ecology of woodland rodents bank voles and wood mice. J. R. Flowerdew, J. Gurnell and J. H. W. Gipps, eds]. Symp. zool. Soc. Lond. 55: $89-115$.

Morris P. A. 1968. Apparent hypothermia in the wood mouse (Apodemus sylvaticus). J. Zool., Lond. 155: $235-236$.

Northcott T. H. 1971. Winter predation of Mustela erminea in Northern Canada. Arctic 24: 141 - 143.

Olszewski J. L. 1968. Role of uprooted trees in the movements of rodents in forests. Oikos 19: $99-104$.

Pulliam H. R. and Caraco T. 1984. Living in groups: is there an optimal group size? [In: Behavioural ecology. An evolutionary approach. J. R. Krebs and N. B. Davies, eds]. Blackwell Scientific Publishers, Oxford: $122-147$.

Schaller G. B. 1972. The Serengeti lion. Univ. Chicago Press, Chicago and London.

Walton J. B. and Andrews J. F. 1981. Torpor induced by food deprivation in the wood mouse Apodemus sylvaticus. J. Zool., Lond. 194: $260-263$.

Wunder B. A. 1984. Strategies for, and environmental cueing mechanisms of, seasonal changes in thermoregulatory parameters of small mammals. [In: Winter ecology of small mammals. J. F. Merritt, ed.]. Carnegie Museum Nat. Hist., Spec. Publ. Pittsburgh. No. 10: 165 - 172.

Ylonen H. 1989. Weasels Mustela nivalis suppress reproduction in cyclic bank voles Clethrionomys glareolus. Oikos 55: $138-140$.

Received 14 July 1992, accepted 10 September 1992.

BIALOWIEZAA

Nakład $950+50$ egz.

Podpisano do druku w pazdzierniku 1992.

Skład, łamanie, diapozytywy: Zakład Badania Ssak6w
Druk: Białostockie Zakłady Graficzne w Białymstoku.
Obj. ark. wyd. 10,60 Obj. ark. druk. 7,25

Druk ukończono w listopadzie 1992.

ruk ukończono w listopadzi

Zam. 1467/92 